\title{
Effect of single-layer versus two-layer gastric suture in epithelialization and pressure bursting in rats
}

\author{
Efeito das suturas gástricas em plano único versus dois planos na \\ epitelização e resistência à pressão em ratos
}

Jeovana Pinheiro Fernandes Souza ${ }^{1}$, Juliana Mendonça Freire' ${ }^{1}$, Lívia Medeiros Soares Celani ${ }^{2}$, Marília Daniela Ferreira de Carvalho Moreira ${ }^{3}$, Irami Araújo-Filho ${ }^{4}$, Aldo Cunha Medeiros $^{5}$

1. Graduate student, Medical School, Federal University of Rio Grande do Norte (UFRN), Natal-RN, Brazil.

2. MD, University Hospital Onofre Lopes, UFRN, Natal-RN, Brazil.

3. PhD, University Hospital Onofre Lopes, UFRN, Natal-RN, Brazil.

4. Associate Professor, PhD, Department of Surgery, UFRN, Natal-RN, Brazil.

5. PhD, Full Professor, Chairman, Nucleus of Experimental Surgery, UFRN, Natal-RN, Brazil.

Study performed at Department of Surgery, Federal University of Rio Grande do Norte (UFRN), Brazil.

Financial support: CNPq.

Conflict of interest: None.

Correspondence address: Department of Surgery, Federal University of Rio Grande do Norte, at Ave. Nilo Peçanha 620, Natal, RN, Brazil. E-mail: cirurgex.ufrn@gmail.com

Submitted: November 16, 2017. Accepted, after review: December 13, 2017.

\section{ABSTRACT}

Purpose: To compare two techniques of suture on the stomach wall. Single-layer and two-layer of gastric suture were compared, evaluating: evolution of the epithelialization process in the gastric mucosa; tensile strength and histopathological changes in the suture area. Methods: Twelve (12) Wistar rats weighing $220 \pm 18 \mathrm{~g}$ were used. Group $1(n=6)$ - Gastric incision was sutured with single interrupted sutures in extramucosal single-layer; group 2 rats $(n=6)$ had the stomach incision sutured in twolayer technique. 6-0 polypropylene thread with atraumatic needle was used. On the seventh postoperative day the animals were anesthetized again to evaluate the tensile strength of the gastric sutures. The stomach healing sutured wound was removed, fixed in $10 \%$ formalin, for histopathological examination using H-E stain. Results: All animals survived the experiments. In the single-layer group pressure supported by the suture line was $247 \pm 30.2 \mathrm{mmHg}$. Compared with the pressure in the two-layer suture group $(187.8 \pm 25.5 \mathrm{mmHg}$ ), the difference was statistically significant $(p<0.05)$. In the single-layer suture group, the aspect of the epithelium in the suture area showed a 
Effect of single-layer versus two-layer gastric suture in epithelialization and pressure bursting in rats Souza JPF, et al

well-structured epithelium, perfect seal, small inflammatory reaction and normal healing compatible within the expected for the 7th postoperative day. In the two-layer suture group we observed an intense inflammatory reaction, and low epithelial regeneration in the suture zone. Conclusion: In conclusion, extramucosal single-plane gastric suture in rats supported higher intragastric pressure than in two-layer suture, and positively influenced the epithelialization on the suture zone.

Key words: Stomach. Gastric suture. Single-layer suture. Pressure bursting. Rat.

\section{RESUMO}

Objetivo: Comparar duas técnicas de sutura na parede do estômago. Plano único e dois planos de sutura gástrica foram comparados, avaliando: evolução do processo de epitelização da mucosa gástrica; força tênsil e alterações histopatológicas na área da

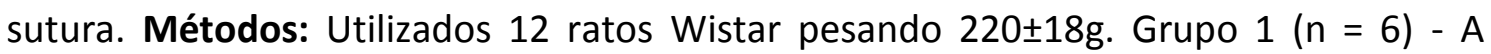
incisão gástrica foi suturada com sutura em plano único,pontos separados, extramucosa. Ratos do grupo $2(n=6)$ tiveram o estômago suturado em dois planos com fio de polipropileno 6-0, agulha atraumática. No sétimo dia pós-operatório, os animais foram anestesiados novamente para avaliar a resistência à tensão das suturas. A peça com a ferida suturada foi removida, fixada em formalina a $10 \%$, para exame histopatológico usando coloração H-E. Resultados: Todos os ratos sobreviveram aos experimentos. No grupo plano único, a pressão suportada pela linha de sutura foi de $247 \pm 30,2 \mathrm{mmHg}$. Comparado com a pressão no grupo de sutura em dois planos $(187,8 \pm 25,5 \mathrm{mmHg})$, a diferença foi estatisticamente significativa $(p<0,05)$. No grupo de sutura em plano único, o aspecto do epitélio na área da sutura mostrou um epitélio bem estruturado, selamento perfeito, pequena reação inflamatória e cicatrização normal compatível com o sétimo dia pós-operatório. No grupo de sutura em dois planos observamos intensa reação inflamatória e baixa regeneração epitelial na zona de sutura. Conclusão: A sutura gástrica extramucosa em plano único suportou maior pressão intragástrica do que a sutura em dois planos e influenciou positivamente a epitelização na zona de sutura.

Descritores: Estômago. Sutura gástrica. Sutura em plano único. Pressão de ruptura. Rato.

\section{INTRODUCTION}

Digestive sutures and anastomoses are the basis of all surgeries of the digestive tract and are the most frequent procedures in abdominal surgery. The operations of the digestive tract have to restore intestinal transit, interrupted when the excision of a 
Effect of single-layer versus two-layer gastric suture in epithelialization and pressure bursting in rats Souza JPF, et al

gastric or intestinal segment is done, to provide the nutrition of the patient. Thus, the reconstruction of digestive transit has been the object of constant investigation in surgery ${ }^{1}$.

Multiple studies in the literature examine the effectiveness of various techniques to perform gastrointestinal anastomosis ${ }^{2}$. In addition, gastrojejunostomy has been reported by the use of several suture techniques including 1-layer or 2-layer techniques. One-layer techniques using a full-thickness simple interrupted, continuous inverting, simple continuous, and continuous vertical mattress have been reported ${ }^{3}$. Leakage and stenosis are an important complications of intestinal anastomosis that are often followed by serious morbidity or death. If the surgical technique is well done, the single-layer anastomosis will be efficient and safe. Despite advances in the technique, there is no consensus that single-layer method can be considered ideal to maintain a coaptation impermeable, resistant and with minimal inflammatory reaction.

The basic principles of intestinal suture were established more than 100 years ago by Travers, Lembert and Halsted, and have since undergone little modification. Development of stapling instruments for gastrointestinal anastomosis has been added to surgery, but here we examined only hand-sewn sutures ${ }^{2,4}$. All surgeons need to be familiar with both techniques. One aspect of gastrointestinal suturing that has remained controversial is the use of either one or two layers of sutures for anastomosis.

In order to obtain a better tissue repair, different techniques of sutures to perform the anastomoses of the digestive tract have been analyzed. Many surgeons probably now use single-layer suturing due to reductions in ischemia, tissue necrosis or narrowing of the lumen compared to the two-layer method.

Several reports have advocated a single-layer anastomosis using monofilament plastic sutures $^{5-7}$. In theory, single-layer anastomosis requires less time to perform, costs less than any other method, and may have a lower risk of leakage. Because of these potential advantages, we hypothesized that the single-layer technique could be better than two-layer gastrointestinal sutures. 
Effect of single-layer versus two-layer gastric suture in epithelialization and pressure bursting in rats Souza JPF, et al

\section{OBJECTIVE}

The objective of the present experimental study was to compare two techniques of suture on the stomach wall of rats. Single-layer and two-layer of gastric suture were compared, evaluating: evolution of the epithelialization process in the gastric mucosa; tensile strength and histopathological changes in the suture area.

\section{METHODS}

This is an exploratory, prospective and experimental study. Twelve (12) Wistar rats weighing $220 \pm 18 \mathrm{~g}$ from the CCS facility of the Federal University of Rio Grande do Norte, Brazil were used. After 12 hours fasting, the animals were all anesthetized with ketamine $70 \mathrm{mg} / \mathrm{kg}$ and xylazine $10 \mathrm{mg} / \mathrm{kg}$ i.p. After depilation and antisepsis with $70 \%$ ethyl alcohol, they were operated with aseptic technique. A median laparotomy gave access to the stomach, which was drawn with Allis forceps to perform the surgical procedure.

Rats were randomly allocated into two groups: group $1(n=6)-$ An incision 5 $\mathrm{cm}$ long was performed in the anterior wall of the stomach and sutured with single interrupted sutures in extramucosal single-layer, ranging from the serosa to the submucosa; In group 2 rats $(n=6)$ the incised anterior wall of the stomach was sutured in two-layer technique. 6-0 polypropylene thread with atraumatic needle was used. Sutures were performed using a surgical microscope (DFV, São Paulo-SP, Brazil) with 10X magnification.

On the seventh postoperative day the animals were anesthetized again to evaluate the tensile strength of the gastric sutures. The distal esophagus was ligated with cotton thread number 00 . The pylorus was opened and catheterized with a plastic vesical tube $10 \mathrm{Fr}$ sealed and fitted to the pyloric wall by ligature. The catheter was connected to a digital tensiometer to measure the rupture pressure of the suture in $\mathrm{mmHg}$. The sutured stomach was immersed in saline solution injected into the abdominal cavity in order to observe the bubbling of $\mathrm{O}_{2}$ when released from gastric lumen at the moment of suture rupture. Oxygen was injected through the catheter 
Effect of single-layer versus two-layer gastric suture in epithelialization and pressure bursting in rats Souza JPF, et al

into the gastric lumen at $0.5 \mathrm{liter} / \mathrm{minute}$ until rupture of the suture was achieved. The stomach was then removed, fixed in $10 \%$ formalin, for histopathological examination of the sutured area for epithelialization and healing. The slides were prepared by the conventional technique and stained with hematoxylin-eosin.

Student's t-test was used to analyze rupture pressure data using BioEstat 5.0 software. Differences were considered significant when $p<0.05$.

\section{RESULTS}

All animals survived the experiments. In the group of rats submitted to singlelayer extramucosal suture the pressure supported by the suture line on the 7th postoperative day was $247 \pm 30.2 \mathrm{mmHg}$. Compared with the pressure in the two-layer suture group (187.8 $\pm 25.5 \mathrm{mmHg}$ ), the difference was statistically significant $(p<0.05)$. These data are summarized in Table 1.

From the histopathological point of view, in the single-layer suture group, the aspect of the epithelium in the suture area showed a well-structured epithelium, perfect seal, small inflammatory reaction and normal healing compatible within the expected for the 7th postoperative day. In the two-layer suture group we observed an intense inflammatory reaction, and low epithelial regeneration in the suture zone. These data can be observed in figures 1 and 2 .

Tabela 1 - Pressure supported by gastric suture $(\mathrm{mmHg})$

\begin{tabular}{ccc}
\hline Rat $\mathbf{n}$ - & Single-layer suture group & Two-layer suture group \\
\hline $\mathbf{1}$ & 278 & 160 \\
\hline $\mathbf{2}$ & 284 & 218 \\
\hline $\mathbf{3}$ & 220 & 178 \\
\hline $\mathbf{4}$ & 225 & 221 \\
\hline $\mathbf{5}$ & 261 & 170 \\
\hline $\mathbf{6}$ & 218 & 180 \\
\hline Mean & $247 \pm 30.2 \mathrm{mmHg}$ & $187.8 \pm 25.5 \mathrm{mmHg}$ \\
\hline
\end{tabular}

Significant difference between mean \pm standard deviation. $\mathrm{P}<0.05$ Teste t Student 
Effect of single-layer versus two-layer gastric suture in epithelialization and pressure bursting in rats Souza JPF, et al
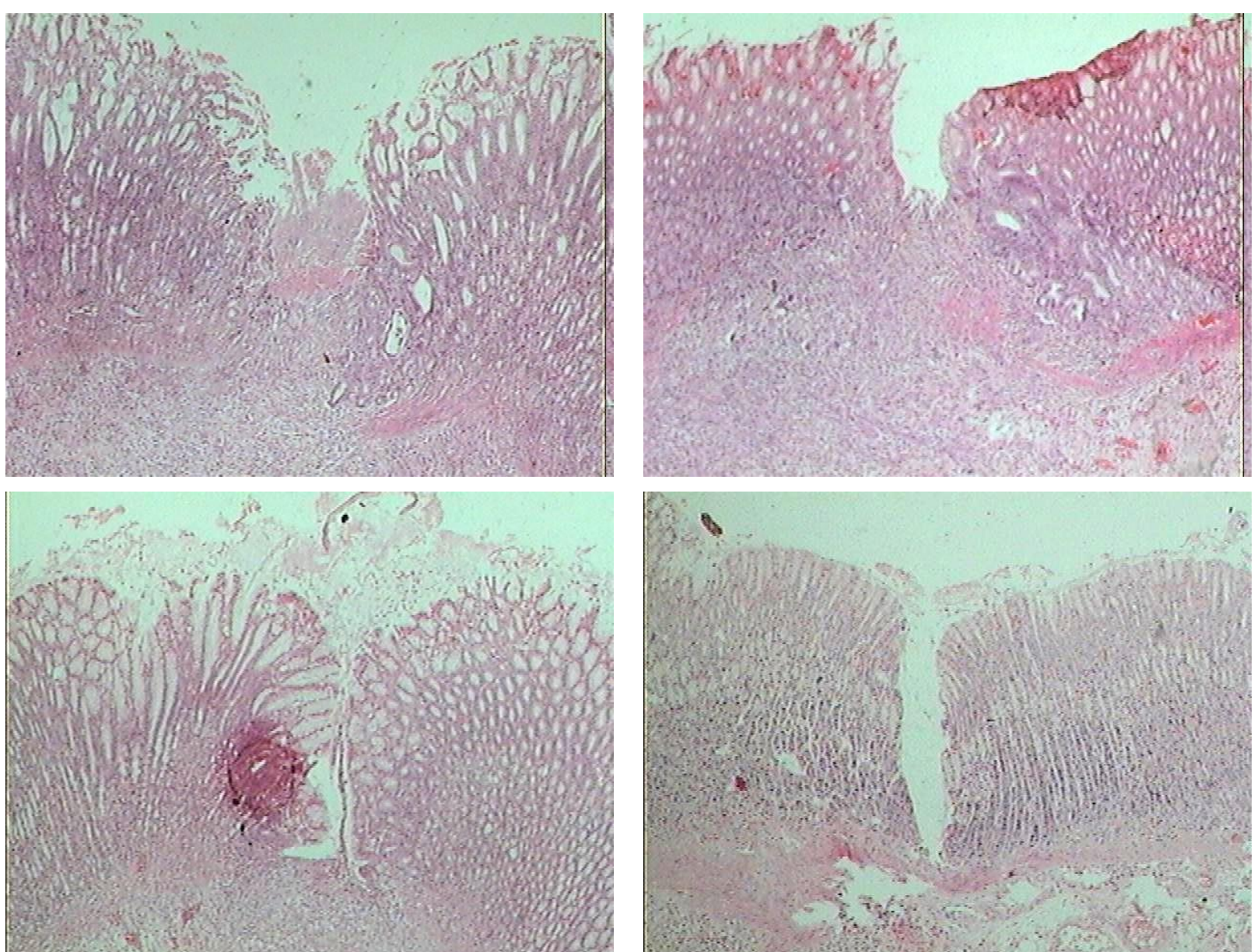

Figure 1 - Single-Layer group. Well structured epithelization in the suture zone of the stomach. Small inflammatory reaction. $\mathrm{HE}, 200 x$. 

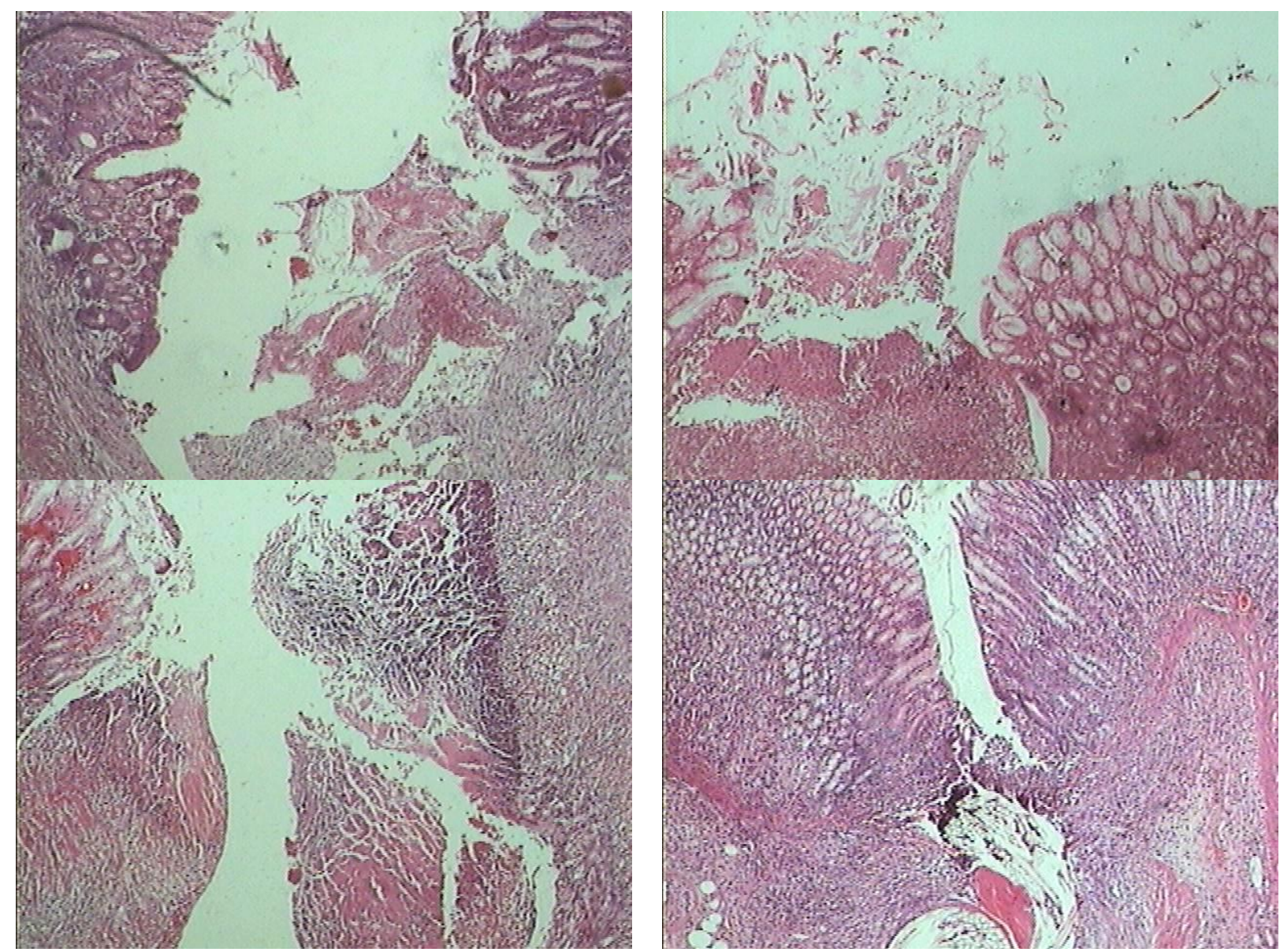

Figure 2 - Two-layer group. Poor epithelization in the suture zone of the stomach; intense inflammatory reaction; edema, sputum formation for gastric lumen and mucosal damage. $\mathrm{H}-\mathrm{E}$, 200x.

\section{DISCUSSION}

Regardless of the surgical procedures used for digestive tract reconstruction, gastrointestinal sutures and anastomoses should provide good hemostasis, good coaptation of the edges without tension, in order to reduce the rate of postoperative complications such as dehiscences, fistulas and stenoses.

The present study assessed the efficacy and safety of single and two-layer gastric sutures after gastric incision. The histopathology of our study addressed: foreign body volume, inflammatory reaction, edema, spur formation for gastric lumen and epithelial failure. Whenever the surgeon practices a gastrointestinal suture or anastomosis he should be aware of the quality of his anastomosis. It should be impermeable, airtight, with regular and coapted edges, without tension in the 
Effect of single-layer versus two-layer gastric suture in epithelialization and pressure bursting in rats Souza JPF, et al

anastomosis zone and, consequently, non-ischemia. The sutures should have well vascularized borders, hemostasis, without stenosis of the intestinal lumen, without adhesions and always performed with mucosa inversion. All these technical details may be present in single-layer sutures and anastomosis ${ }^{8}$.

A meta-analysis study pointed that although various endpoints can be used to assess efficacy and safety of intestinal anastomosis, risk of leak after operation occupies the greatest attention among surgeons ${ }^{9}$. The meta-analysis ${ }^{9}$ concluded that two-layer intestinal anastomosis offers no definite advantage over single-layer anastomosis in terms of postoperative leak. The authors pointed that considering duration of the surgical procedure and medical expenses, single-layer intestinal anastomosis may prove the optimal choice in most surgical situations. Because there is no difference in the main outcome between two techniques, choices in surgical practice should be made after taking into account the results of other outcomes such as mortality, duration of anastomosis procedure, length of hospital stay, risk of wound infection, and cost of sutures. Arithmetical means of these endpoints suggests that the single-layer method offers better results than the two-layer method ${ }^{9}$.

The single-layer gastric suture in our study presented advantages when compared with the two-layer suture. The single-layer underwent higher rupture pressure and more favorable histopathological data then two-layer suture, especially the good quality of the mucosa epithelialization. Because of these potential advantages, the single-layer technique could be introduced into residence surgical teaching programs. It requires single training and it could be learned and performed in less time than the two-layer technique.

In conclusion, extramucosal single-plane gastric suture in rats supported higher intragastric pressure than in two-layer suture, and positively influenced the epithelialization on the suture zone. 
Effect of single-layer versus two-layer gastric suture in epithelialization and pressure bursting in rats

Souza JPF, et al

\section{REFERENCES}

1. Burch JM, Franciose RJ, Moore EE, BiffI WL, Offner PJ. Single-layer continuous versus two-layer interrupted intestinal anastomosis: a prospective randomized trial. Ann Surg.. 2000, 231: 832-837.

2. MacRae HM, McLeod RS: Handsewn vs. stapled anastomoses in colon and rectal surgery: a meta-analysis. Dis Colon Rectum. 1998, 41:180-189

3. Tanimura S, Higashino M, Fukunaga $Y$, et al. Laparoscopic gastrectomy with regional lymph node dissection for upper gastric cancer. Surg Endosc. 2004;6:64-68.

4. Lustosa SA, Matos D, Atallh AN, Castro AA. Stapled versus handsewn methods for colorectal anastomosis surgery: a systematic review of randomized controlled trials. Sao Paulo Med J. 2002, 120:132-136.

5. AhChong AK, Chiu KM, Law IC, et al. Single-layer continuous anastomosis in gastrointestinal surgery: a prospective audit. Aust NZ J Surg. 1996; 66:34 -6.

6. Brodsky JT, Dadian N. Single-layer continuous suture for gastrojejunostomy. Am Surg 1997; 63:395-8.

7. Law WL, Bailey HR, Max E, et al. Single-layer continuous colon and rectal anastomosis using monofilament absorbable suture (Maxon): study of 500 cases. Dis Colon Rectum. 1999; 42:736 -40.

8. Azevedo JLMC, Silva CEP, Azevedo OC, Simões MJ. Técnicas de sutura do tubo digestivo em plano único com nós atados no lume, em cães: pontos simples totais versus pontos extramucosos. Acta Cir Bras. 2005, 20: 168-73.

9. Shikata S, Yamagishi H, Taji Y, Shimada T, Noguchi Y. Single versus two-layer intestinal anastomosis: a meta-analysis of randomized controlled trials. BMC Surg. 2006;6:2-7. 